\title{
Boron enhances the antiviral activity of the curcumin against SARS-CoV-2
}

\author{
ION ROMULUS SCOREI ${ }^{1)}$, ANDREI BITĂ ${ }^{1,2)}$, GEORGE DAN MOGOŞANU ${ }^{1,2)}$ \\ 1) BioBoron Research Institute, S.C. Natural Research S.R.L., Podari, Dolj County, Romania \\ 2) Department of Pharmacognosy \& Phytotherapy, Faculty of Pharmacy, University of Medicine and Pharmacy of Craiova, \\ Romania
}

\section{Dear Editor,}

Unfortunately, today we are in the situation during the severe acute respiratory syndrome coronavirus 2 (SARSCoV-2) pandemic that there are no standardized vaccines or treatments yet [1]. In addition, the long incubation period of 3-7 days of virus infection, without clear evidence of the disease and the very high ability to spread the infection, made SARS-CoV-2 one of the most dangerous, especially for elderly patients and those who have meet major health problems. For now, it is known that SARS-CoV-2 invades the host cell through two receptors: angiotensin-converting enzyme 2 (ACE2) and cluster of differentiation 147 (CD147) [1-4]. Probably, there are other receptors, still undiscovered, which might have a major significance in the fight against coronavirus disease 2019 (COVID-19). Recent studies report that the neuropilin-1 receptor and the humanized transferrin receptor (an omnipresent expressed host receptor on cell membranes) represent host factors for COVID-19 infection [5-7]. In the past, CD147 has been identified as a receptor for red blood cells for infection with the Plasmodium falciparum parasite (protozoan causing malaria in humans) [8]. Recent research shows that human red blood cells are strongly involved in the pathophysiology of COVID-19 [9].

Over the years, curcumin solutions or turmeric extracts have been used as coloring analytical reagents to assess the amount of boron in soil, water, and food [10]. Curcumin can be found in two tautomeric conformations (keto- and enol-), with many cis and trans isomers, which can vary depending on $\mathrm{pH}$, solvent polarity, temperature. These conformations play a very important role in the antioxidant activity of curcumin, as well as on its physical and chemical properties [11]. Curcumin is insoluble in water at neutral $\mathrm{pH}$, so it has low bioavailability and also decomposes and/or crystallizes into acidic or alkaline $\mathrm{pH}$ solutions. When taken orally, the largest amount of curcumin never reaches the bloodstream, being barely absorbed from the intestine, rapidly metabolized, and excreted in the feces. Although curcumin has been evaluated in numerous laboratory and clinical studies, it has not yet established medical uses. According to a 2017 scientific review that covered more than 120 studies, curcumin was not successful in any clinical trials, leading the authors to conclude that curcumin is an unstable, reactive compound with low bioavailability and therefore in its natural form it is extremely unlikely to be used as a medicine [12].

Then, the interactive potential of curcumin with spike ('S') protein binding was demonstrated only theoretically, in silico, which revealed that curcumin could prevent the attachment of SARS-CoV-2 to the host surface, inhibiting this virus in the range of 3-10 $\mu \mathrm{M}$ concentrations. This concentration is similar to that of nelfinavir (an important antiviral drug) [13]. Recently, in silico, it has also been shown that curcumin together with hydroxychloroquine can destabilize the structural integrity of SARS-CoV-2 surface proteins, resulting in a hypothesis for the in vivo combined therapy of curcumin together with hydroxychloroquine [14]. Other theoretical experiments in silico show that curcumin, capsaicin and piperine bind strongly to the $3 \mathrm{C}$-like protease $\left(3 \mathrm{CL}^{\text {pro }}\right)$ protein of SARS-CoV-2 and promote important structural changes in this viral protease [15].

Due to its special chemical structure, curcumin can be an excellent chelating agent (the chemical binding process of metal ions) [16]. When combined with boric acid, its esters form a complex called rosocyanine, which is regularly used to assess the amount of boron in various organic and inorganic matrices [17]. The use of rosocyanine for the development of antibacterial, anticancer, and antifungal drugs has led to an increased presence of boron in the pharmaceutical industry [18]. At $\mathrm{pH} 2$, rosocyanine proves a charged structure due to the two $\mathrm{OH}^{+}$functional groups of the benzene ring, while at $\mathrm{pH} 3-5$ it has a nonionic structure [18]. The use of boron-based compounds by reaction with curcumin, it improves its stability in vivo without loss of bioactivity. Recently, a study showed that the drug bortezomib co-administered with curcumin determines the synergistic and therapeutic activity for the treatment of multiple myeloma. Moreover, the combination of 2-aminoethyl diphenyl borate with curcumin has been shown to increase the in vitro and in vivo stability of curcumin [19].

This is an open-access article distributed under the terms of a Creative Commons Attribution-NonCommercial-ShareAlike 4.0 International Public License, which permits unrestricted use, adaptation, distribution and reproduction in any medium, non-commercially, provided the new creations are licensed under identical terms as the original work and the original work is properly cited. 
It is well known that curcumin' inhibition activity on human immunodeficiency virus (HIV)-1 and HIV-2 proteases was reduced, while when rosocyanine was used its inhibition activity on HIV-1 and HIV-2 proteases increased more than 10-fold [20]. As a result, boron compounds with curcumin began to be investigated more and more, discovering remarkable biological properties (antitumor, antiviral, antioxidant, antithrombotic). It is believed that in the future these compounds could be used as drugs in the prophylaxis of pandemic viral attacks, such as SARS-CoV-2, as well as to improve blood circulation in the body. Considering the scientific arguments presented above and also the ability of curcumin to form boron complexes, several boron-based compounds could be prepared for the prevention of COVID-19 viral disease [21].

Heterozygous beta-thalassemia (HBT) is a benign genetic deficiency of the blood caused by a hereditary reduction in beta-globin synthesis. HBT is prevalent in many regions of the world, including the Mediterranean countries, the northern coast of Africa, the Middle East, Central Asia, Southeast Asia, the Far East, and South America. The highest frequencies carrying beta-thalassemia were reported in Cyprus (14\%), Sardinia (10.3\%) and Southeast Asia (Cambodia, Bangladesh, Thailand, Laos, etc.) [22]. The population with HBT has developed a defense mechanism for bacteria and viruses that attack the blood through the action of two toxic factors: low blood iron levels and the presence of free hemin [porphyrin that contains iron(III) and chloride]. Probably the same mechanism is happening in case of SARS-CoV-2 infection too. The above-mentioned countries had and still have a very small population infected with SARS-CoV-2 [23, 24].

In order to help elucidating future treatment decisions for COVID-19, we are proposing that the HBT model to protect the blood against SARS-CoV-2 infection. Thus, we propose to utilize the following two classes of natural compounds suited for defending the blood against SARS-CoV-2: hemin and boron-curcumin complexes. The advantages of the HBT model in identifying prophylactic and therapeutic strategies against COVID-19 are related to the following physiological aspects:

(i) HO-1 has a significant activity in the spleen of HBT patients in the degradation of hemoglobin during red blood cells recycling $(0.8 \%$ of the red blood cells fund per day), which represents approximately $80 \%$ of the production of endogenous carbon monoxide (CO)-derived heme [25].

(ii) HBT patients have hemin concentration in the blood, while normal people have a total lack of free hemin [23].

(iii) In HBT patients, erythropoietin (EPO), the hormone that regulates erythrocyte production, is also dramatically increased in response to anemia and hypoxia. EPO-induced HO-1 expression is likely to provide cytoprotection against oxidative stress [26]. These effects are actually a link between EPO and HO-1. In addition to HO-1 induction, EPO can exert its antioxidant effects by inducing antioxidant enzymes, such as superoxide dismutase, catalase, and glutathione peroxidase $[27,28]$.

(iv) Two platelet function markers belonging to the group of membrane glycoproteins - selectin $\mathrm{P}$ and serum soluble cluster of differentiation 40 ligand (sCD40L) - were present at lower levels in individuals with HBT compared to controls [29]. Subjects with HBT have a lower frequency of cardiac and cerebral ischemic events than controls in some studies and this difference was supported by a meta-analysis and recently multiple sclerosis is very low in thalassemics [30].

HO-1 is a metabolic enzyme that catalyzes the degradation of heme into CO, biliverdin and free iron [25]. This enzyme has anti-inflammatory and antioxidant properties, which modulate innate and adaptive immune responses. In addition, recent studies have reported that HO-1 may exert significant antiviral activity against a wide variety of viruses, including HIV, hepatitis C virus, hepatitis B virus, enterovirus 71, influenza virus, respiratory syncytial virus, dengue virus, and Ebola virus, among others [31]. The activation of HO-1 by its substrate hemin ensured the protection against HIV infection. Treatments against viral infections that enhance HO-1 include various anesthetics (isoflurane or sevoflurane), hemin, estrogen, statins, curcumin, resveratrol, and melatonin [32]. Therefore, HO-1 expression can be strongly induced by heme analogues, such as hemin and curcumin derivatives, such as boron-curcumin complexes $[33,34]$.

Lymphocytopenia is a common feature of SARS-Cov-2 infection, which can be used as an early marker in patients with SARS-CoV-2 infections, and is more pronounced in patients infected with SARS-CoV-2. Current data show that hemin can ameliorate lung damage resulting from virus infection. In addition, reports indicate that hemin may alleviate lung damage caused by other factors, such as lipopolysaccharide, mechanical ventilation, complement activation, and transfusion. All these results suggest that the effect of hemin in protecting the lungs has a broad spectrum and potentially involves against several diseases in the clinical setting [35].

Do rosocyanine (boron-curcumin) and hemin [iron(III)-porphyrin chloride] act against SARS-CoV-2? The following candidate molecules could be able to ensure very good blood protection against SARS-CoV-2:

(i) Rosocyanine is a promising and inexpensive alternative used in the photodynamic inactivation of viruses. Rosocyanine has been shown to be an extremely effective inhibitor of viral proteases (HIV-1 and HIV-2) and in addition a potent chelator of free iron. Taking into consideration the above-presented scientific arguments and also the capacity of curcumin to form boron adducts, several boron-based curcumin nutraceuticals could be prepared for viral disease (COVID-19) prevention [36].

(ii) Hemin, a commercial heme compound, used as an inducer of HO-1 has been shown to have antiviral activity. Hemin has been approved as a drug by the Food and Drug Administration (FDA) for use in patients with acute porphyria since the 1970s. Scientific data show that protoporphyrin, hemin and other natural porphyrins, as well as related 
metalloporphyrins, have activity against ribonucleic acid (RNA) viruses through an inhibition mechanism of viral enveloped proteases. In addition, it is also known that porphyrins can be a remarkable viral trap (for SARS-CoV-2 too), as they can be intercalated in the host cell membranes affecting the fusion of the virus with the human body. Considering the present demand of medication, it could be worth testing the antiviral properties and safety of hemin against COVID-19 [37]. Various compelling evidence indicate a possible role for hemin-induced HO-1 as a therapy strategy against the SARS-CoV-2-induced cytokine storm syndrome. Hemin-induced HO-1 might be a harmless, novel, and promising approach for controlling SARS-CoV-2 infection and limiting cytokine [38].

Recently, it has been hypothesized that heterozygous patients with HBT would develop resistance against SARSCoV-2 due to the absence of the beta chain in hemoglobin (potential target of the virus). This hypothesis has been studied starting from the high percentages of the beta-thalassemia population present in four areas of Italy: Sardinia, Sicily, Puglia, and Emilia Romagna [39, 40]. To this end, there are two classes of natural compounds suitable for protecting the blood against SARS-CoV-2: exogenous porphyrins [41] and boron-curcumin compounds [3]. Our current approaches for prophylaxis and treatment for COVID-19, based on HBT model and on using iron as a "bargaining chip" for blood protection and boron-curcumin complex as well, should be taken into consideration by specialized agencies - FDA, World Health Organization (WHO), European Medicines Agency (EMA). We believe that new decisions for COVID-19 prophylaxis and treatment are being actually imperative due to the spread of SARS-CoV-2 infections at the present moment.

\section{Conflict of interests}

The authors declare that they have no conflict of interests.

\section{Ethics approval}

This article did not contain human participants or animals.

\section{Funding}

This research did not receive any specific grant from funding agencies in the public, commercial, or not-for-profit sectors.

\section{References}

[1] Zhai P, Ding Y, Wu X, Long J, Zhong Y, Li Y. The epidemiology, diagnosis and treatment of COVID-19. Int J Antimicrob Agents 2020, 55(5):105955. https://doi.org/10.1016/j.ijantimicag.2020.105955 PMID: 32234468 PMCID: PMC7138178

[2] Ulrich H, Pillat MM. CD147 as a target for COVID-19 treatment: suggested effects of azithromycin and stem cell engagement. Stem Cell Rev Rep 2020, 16(3):434-440. https://doi.org/10.1007/s12015-020-09976-7 PMID: 32307653 PMCID: PMC7167302

[3] Wang K, Chen W, Zhou Y, Lian J, Zhang Z, Du P, Gong L, Zhang Y, Cui H, Geng J, Wang B, Sun X, Wang C, Yang X, Lin P Deng Y, Wei D, Yang X, Zhu Y, Zhang K, Zheng Z, Miao J, Guo T, Shi Y, Zhang J, Fu L, Wang Q, Bian H, Zhu P, Chen Z. SARSCoV-2 invades host cells via a novel route: CD147-spike protein. bioRxiv, 2020, PPR117474. https://doi.org/10.1101/2020.03. 14.988345

[4] Liu C, von Brunn A, Zhu D. Cyclophilin A and CD147: novel therapeutic targets for the treatment of COVID-19. Med Drug Discov, 2020, 7:100056. https://doi.org/10.1016/j.medidd.2020.100056 PMID: 32835213 PMCID: PMC7364167

[5] Tang X, Yang M, Duan Z, Liao Z, Liu L, Cheng R, Fang M, Wang G, Liu H, Xu J, Kamau PM, Zhang Z, Yang L, Zhao X, Peng X, Lai R. Transferrin receptor is another receptor for SARS-CoV-2 entry. bioRxiv, 2020, PPR: PPR229858. https://doi.org/10.1101/ 2020.10.23.350348

[6] Daly JL, Simonetti B, Antón-Plágaro C, Kavanagh Williamson M, Shoemark DK, Simón-Gracia L, Klein K, Bauer M, Hollandi R, Greber UF, Horvath P, Sessions RB, Helenius A, Hiscox JA, Teesalu T, Matthews DA, Davidson AD, Cullen PJ, Yamauchi Y. Neuropilin-1 is a host factor for SARS-CoV-2 infection. bioRxiv, 2020, PPR: PPR172518. https://doi.org/10.1101/2020.06.05. 134114

[7] Cantuti-Castelvetri L, Ojha R, Pedro LD, Djannatian M, Franz J, Kuivanen S, van der Meer F, Kallio K, Kaya T, Anastasina M, Smura T, Levanov L, Szirovicza L, Tobi A, Kallio-Kokko H, Österlund P, Joensuu M, Meunier FA, Butcher SJ, Winkler MS, Mollenhauer B, Helenius A, Gokce O, Teesalu T, Hepojoki J, Vapalahti O, Stadelmann C, Balistreri G, Simons M. Neuropilin-1 facilitates SARS-CoV-2 cell entry and infectivity. Science, 2020, 370(6518):856-860. https://doi.org/10.1126/science.abd2985 PMID: 33082293

[8] Zhang MY, Zhang Y, Wu XD, Zhang K, Lin P, Bian HJ, Qin MM, Huang W, Wei D, Zhang Z, Wu J, Chen R, Feng F, Wang B, Nan G, Zhu P, Chen ZN. Disrupting CD147-RAP2 interaction abrogates erythrocyte invasion by Plasmodium falciparum. Blood, 2018, 131(10):1111-1121. https://doi.org/10.1182/blood-2017-08-802918 PMID: 29352039 PMCID: PMC5854849

[9] Abrahams L. Covid-19: acquired acute porphyria hypothesis (edited). OSF Preprints, 2020, Apr 16. https://doi.org/10.31219/osf.io/ 4wkfy

[10] Mohan TC, Jones AME. Determination of boron content using a simple and rapid miniaturized curcumin assay. Bio Protoc, 2018, 8(2):e2703. https://doi.org/10.21769/BioProtoc.2703 PMID: 29430483 PMCID: PMC5802381

[11] Slabber CA, Grimmer CD, Robinson RS. Solution conformations of curcumin in DMSO. J Nat Prod, 2016, 79(10):2726-2730. https://doi.org/10.1021/acs.jnatprod.6b00726 PMID: 27715050

[12] Nelson KM, Dahlin JL, Bisson J, Graham J, Pauli GF, Walters MA. The essential medicinal chemistry of curcumin. J Med Chem, 2017, 60(5):1620-1637. https://doi.org/10.1021/acs.jmedchem.6b00975 PMID: 28074653 PMCID: PMC5346970

[13] Khaerunnisa S, Kurniawan H, Awaluddin R, Suhartati S, Soetjipto S. Potential inhibitor of COVID-19 main protease (Mro) from several medicinal plant compounds by molecular docking study. Preprints, 2020, PPR: PPR117346. https://doi.org/10.20944/ preprints202003.0226.v1

[14] Srivastava A, Singh D. Destabilizing the structural integrity of SARS-CoV-2 receptor proteins by curcumin along with hydroxychloroquine: an in silico approach for a combination therapy. ChemRxiv, 2020, PPR: PPR149919. https://doi.org/10.26434/ chemrxiv.12090438.v1

[15] Gonzalez-Paz LA, Lossada CA, Moncayo LS, Romero F, Paz JL, Vera-Villalobos J, Pérez AE, San-Blas E, Alvarado YJ. Theoretical molecular docking study of the structural disruption of the viral 3CL-protease of COVID19 induced by binding of capsaicin, piperine and curcumin. Part 1: A comparative study with chloroquine and hydrochloroquine two antimalaric drugs. Res Square, 2020, PPR: PPR140818. https://doi.org/10.21203/rs.3.rs-21206/v1 
[16] Wanninger S, Lorenz V, Subhan A, Edelmann FT. Metal complexes of curcumin - synthetic strategies, structures and medicinal applications. Chem Soc Rev, 2015, 44(15):4986-5002. https://doi.org/10.1039/c5cs00088b PMID: 25964104

[17] Bellamy LJ, Spicer GS, Strickland JDH. 908. Compounds of curcumin and boric acid. Part III. Infra-red studies of rosocyanin and allied compounds. J Chem Soc, 1952, 4653-4656. https://doi.org/10.1039/JR9520004653

[18] John J, Rugmini SD, Nair BS. Kinetics and mechanism of the thermal and hydrolytic decomposition reaction of rosocyanin. Int J Chem Kinet, 2018, 50(3):164-177. https://doi.org/10.1002/kin.21148

[19] Kim JY, Kang YY, Kim EJ, Ahn JH, Mok H. Effects of curcumin-/boron-based compound complexation on antioxidant and antiproliferation activity. Appl Biol Chem, 2018, 61(2):403-408. https://doi.org/10.1007/s13765-018-0374-4

[20] Sui Z, Salto R, Li J, Craik C, Ortiz de Montellano PR. Inhibition of the HIV-1 and HIV-2 proteases by curcumin and curcumin boron complexes. Bioorg Med Chem, 1993, 1(6):415-422. https://doi.org/10.1016/s0968-0896(00)82152-5 PMID: 8087563

[21] Vega-Valdez IR, Santiago-Quintana JM, Rosalez MN, Farfán-García ED, Soriano-Ursúa MA. Theoretical evaluation of bortezomib and other boron-containing compounds as inhibitors of SARS-CoV-2 main protease. ChemRxiv, 2020, PPR: PPR134220. https:// doi.org/10.26434/chemrxiv.12047346.v1

[22] Cao A, Galanello R. $\beta$-Thalassemia. Genet Med, 2010, 12(2):61-76. https://doi.org/10.1097/GIM.0b013e3181cd68ed PMID: 20098328

[23] Phumala N, Porasuphatana S, Unchern S, Pootrakul P, Fucharoen S, Chantharaksri U. Hemin: a possible cause of oxidative stress in blood circulation of $\beta$-thalassemia/hemoglobin E disease. Free Radic Res, 2003, 37(2):129-135. https://doi.org/10.1080/ 1071576031000060607 PMID: 12653201

[24] Hirsch RE, Sibmooh N, Fucharoen S, Friedman JM. HbE/ $\beta$-thalassemia and oxidative stress: the key to pathophysiological mechanisms and novel therapeutics. Antioxid Redox Signal, 2017, 26(14):794-813. https://doi.org/10.1089/ars.2016.6806 PMID: 27650096 PMCID: PMC5421591

[25] Sposi NM. Oxidative stress and iron overload in $\beta$-thalassemia: an overview. In: Zakaria M, Hassan TH (eds). Beta thalassemia. IntechOpen Ltd., London, 2019, pp. 1-17. https://doi.org/10.5772/intechopen.90492

[26] Katavetin P, Inagi R, Miyata T, Shao J, Sassa R, Adler S, Eto N, Kato H, Fujita T, Nangaku M. Erythropoietin induces heme oxygenase-1 expression and attenuates oxidative stress. Biochem Biophys Res Commun, 2007, 359(4):928-934. https://doi.org/ 10.1016/j.bbrc.2007.05.207 PMID: 17560935

[27] Calò LA, Davis PA, Piccoli A, Pessina AC. A role for heme oxygenase-1 in the antioxidant and antiapoptotic effects of erythropoietin: the start of a good news/bad news story? Nephron Physiol, 2006, 103(3):107-111. https://doi.org/10.1159/000092213 PMID: 16554668

[28] Katavetin P, Tungsanga K, Eiam-Ong S, Nangaku M. Antioxidative effects of erythropoietin. Kidney Int Suppl, 2007, (107):S10S15. https://doi.org/10.1038/sj.ki.5002482 PMID: 17943138

[29] Lim HS, Blann AD, Lip GYH. Soluble CD40 ligand, soluble P-selectin, interleukin-6, and tissue factor in diabetes mellitus: relationships to cardiovascular disease and risk factor intervention. Circulation, 2004, 109(21):2524-2528. https://doi.org/10.1161/01.CIR.0000 129773.70647.94 PMID: 15136493

[30] Cikrikcioglu MA, Ozcan ME, Halac G, Gultepe I, Celik K, Sekin Y, Eser EE, Burhan S, Cetin G, Uysal O. Could heterozygous beta thalassemia provide protection against multiple sclerosis? Med Sci Monit, 2016, 22:4854-4858. https://doi.org/10.12659/msm. 898192 PMID: 27941710 PMCID: PMC5154712

[31] Espinoza JA, González PA, Kalergis AM. Modulation of antiviral immunity by heme oxygenase-1. Am J Pathol, 2017, 187(3):48793. https://doi.org/10.1016/j.ajpath.2016.11.011 PMID: 28082120

[32] Hooper PL. COVID-19 and heme oxygenase: novel insight into the disease and potential therapies. Cell Stress Chaperones, 2020, 25(5):707-710. https://doi.org/10.1007/s12192-020-01126-9 PMID: 32500379 PMCID: PMC7271958

[33] Yang $\mathrm{X}$, Jiang $\mathrm{H}$, Shi Y. Upregulation of heme oxygenase-1 expression by curcumin conferring protection from hydrogen peroxideinduced apoptosis in H9c2 cardiomyoblasts. Cell Biosci, 2017, 7:20. https://doi.org/10.1186/s13578-017-0146-6 PMID: 28439402 PMCID: PMC5401460

[34] Mohammed F, Rashid-Doubell F, Taha S, Cassidy S, Fredericks S. Effects of curcumin complexes on MDA-MB-231 breast cancer cell proliferation. Int J Oncol, 2020, 57(2):445-455. https://doi.org/10.3892/ijo.2020.5065 PMID: 32626932 PMCID: PMC7307592

[35] Tan L, Wang Q, Zhang D, Ding J, Huang Q, Tang YQ, Wang Q, Miao H. Lymphopenia predicts disease severity of COVID-19: a descriptive and predictive study. Signal Transduct Target Ther, 2020, 5(1):33. https://doi.org/10.1038/s41392-020-0148-4 PMID: 32296069 PMCID: PMC7100419

[36] Biţă A, Scorei IR, Mogoantă L, Bejenaru C, Mogoşanu GD, Bejenaru LE. Natural and semisynthetic candidate molecules for COVID-19 prophylaxis and treatment. Rom J Morphol Embryol, 2020, 61(2):321-334. https://doi.org/10.47162/RJME.61.2.02 PMID: 33544784 PMCID: PMC7864303

[37] Herraiz T. Chloroquine and hydroxychloroquine as antimalarials and antivirals against SARS-CoV-2: the hemin factor. OSF Preprints, 2020, Jun 2. https://doi.org/10.31219/osf.io/8d6xv

[38] Rossi M, Piagnerelli M, Van Meerhaeghe A, Boudjeltia KZ. Heme oxygenase-1 (HO-1) cytoprotective pathway: a potential treatment strategy against coronavirus disease 2019 (COVID-19)-induced cytokine storm syndrome. Med Hypotheses, 2020, 144:110242. https://doi.org/10.1016/j.mehy.2020.110242 PMCID: PMC7467863

[39] Lansiaux E, Pébay PP, Picard JL, Son-Forget J. COVID-19: beta-thalassemia subjects immunised? Med Hypotheses, 2020, 142:109827. https://doi.org/10.1016/j.mehy.2020.109827 PMID: 32447232 PMCID: PMC7217120

[40] Drouin E. Beta-thalassemia may protect against COVID 19. Med Hypotheses, 2020, 143:110014. https://doi.org/10.1016/j.mehy. 2020.110014 PMID: 32615501 PMCID: PMC7321655

[41] Guo H, Pan X, Mao R, Zhang X, Wang L, Lu X, Chang J, Guo JT, Passic S, Krebs FC, Wigdahl B, Warren TK, Retterer CJ, Bavari S, Xu X, Cuconati A, Block TM. Alkylated porphyrins have broad antiviral activity against hepadnaviruses, flaviviruses, filoviruses, and arenaviruses. Antimicrob Agents Chemother, 2011, 55(2):478-486. https://doi.org/10.1128/AAC.00989-10 PMID: 21135183 PMCID: PMC3028764

\section{Corresponding author}

Ion Romulus Scorei, Professor, Biochem, PhD, BioBoron Research Institute, S.C. Natural Research S.R.L., 31B Dunării Street, 207465 Podari, Dolj County, Romania; Phone +40351-407 543, e-mail: romulus_ion@yahoo.com 